\title{
THE EFFECTS OF PROCESS-ROUTE VARIATIONS ON THE TENSILE PROPERTIES OF CLOSED-DIE WASPALOY FORGINGS, VIA STATISTICAL MODELLING TECHNIQUES
}

\author{
A.O. Latinwo, B.P Wynne, W. M. Rainforth \\ 1 IMMPETUS, Institute of Microstructure and Mechanical Process Engineering: \\ The University of Sheffield, UK
}

Keywords: Closed-Die, modelling, Regression, Waspaloy, Forging, Mechanical properties

\begin{abstract}
Statistical data modelling techniques are used to predict and optimise the tensile properties of a 2-stage closed-die Waspaloy forging using real industrial data. This data includes chemical composition, inner and outer region billet grain size, $\gamma^{\prime}$ solvus temperature, furnace set temperature and preform and final form furnace durations. These parameters are used to model the behaviour of the ultimate tensile strength (UTS), yield strength (YS), elongation (E) and the reduction of area ( $\mathrm{R}$ of $\mathrm{A}$ ), at 8 varied locations in the forging via linear and non-linear regression. This has been done to determine the sensitivity of variations in process route and alloy chemistry, in order to optimise tensile properties.
\end{abstract}

\section{Introduction}

A typical process route for critical section Waspaloy forgings involves a 2 stage forging operation, using 2 separate dies with perform and final heat treatments, followed by air cooling. They then undergo 3 heat treatment stages: a solution heat treatment, a stabilisation and an ageing process. Mechanical property assessment is then done on a number of sacrificial forgings within the batch at different locations in order to determine if the products reach customer specification and have a high degree of consistency.

The aim of this work is to determine the effect of process route variations using various statistical data modelling analyses. This is based on the notion that the majority of the forging process route is constant and the only means of influencing tensile properties would be via the obtained parameters. These relationships may then be reverse engineered to provide optimum process routes that provide more reliable products thus eliminating time and money spent on non-conformance investigations. As such the work has two objectives:

1. Verify the significance of altering each input independently of other factors, which is not always applicable industrially.

2. Highlight the variations in modelling accuracies in the modelling of UTS, YS, E and R of A and how variations in process route to optimise one property have an influence on the other properties. 


\section{Experimental}

This study uses real industrial data obtained from a single part with 8 test locations to find and quantify correlations between the billet characteristics/process route and tensile properties. This resulted in over 2660 data points for modelling. The 20 inputs and 4 outputs measured for the part were the following:

PROCESS INPUTS
Major Compositional Elements (taking Ni as balanced)
$\mathrm{Al}, \mathrm{Ti}, \mathrm{C}, \mathrm{Cr}, \mathrm{Cu}, \mathrm{Co}, \mathrm{S}, \mathrm{P}, \mathrm{B}, \mathrm{Fe}, \mathrm{Zr}, \mathrm{Mn}, \mathrm{Si}, \mathrm{Mo}($ all measured in Wt. \% composition)
Billet Characteristics

Table I. shows the range in which the data was obtained.

Table I: Maximum and minimum ranges of all Inputs/Outputs used in this investigation.

\begin{tabular}{|c|c|c|c|c|c|c|c|c|c|c|c|c|c|c|}
\hline Data & \multirow{6}{*}{ 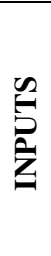 } & $\mathrm{C}$ & $\mathbf{T i}$ & $\mathbf{P}$ & $\mathbf{Z r}$ & Mn & Co & Al & $\mathrm{Cu}$ & Si & $\mathrm{Fe}$ & B & $\mathrm{Cr}$ & Mo \\
\hline Max & & 0.037 & 3.12 & 0.004 & 0.071 & 0.06 & 13.46 & 1.35 & 0.02 & 0.10 & 1.50 & 0.0055 & 19.40 & 4.14 \\
\hline Min & & 0.031 & 3.02 & 0.001 & 0.060 & 0.01 & 13.20 & 1.29 & 0.01 & 0.03 & 0.55 & 0.0041 & 18.88 & 3.86 \\
\hline Data & & $\mathbf{S}$ & $\begin{array}{c}\text { C. } \\
\text { GS }\end{array}$ & $\begin{array}{l}\text { E. } \\
\text { GS }\end{array}$ & $\gamma^{\prime} S$ & $\begin{array}{c}\text { F. S. } \\
\text { T. }\end{array}$ & P. D & $\begin{array}{l}\text { F. } \\
\text { D }\end{array}$ & \multirow{3}{*}{ 它定 } & UTS & YS & $\mathbf{E}$ & \multicolumn{2}{|c|}{$R$ of $A$} \\
\hline Max & & 0.0005 & 7.5 & 12.0 & 1919.5 & 1028 & 276 & 178 & & 1473.6 & 1082.3 & 28.43 & \multicolumn{2}{|c|}{44.96} \\
\hline Min & & 0.0001 & 3.5 & 5.5 & 1905.0 & 1016 & 108 & 61 & & 1258.7 & 842.0 & 16.30 & \multicolumn{2}{|c|}{19.00} \\
\hline
\end{tabular}

$1^{\text {st }}$ stage data analysis was to normalise all the data (between 0 and 1) with regards to their individual data ranges. This made sure that there was no scalar bias towards the larger valued inputs and allowed models for various process inputs and outputs to be directly comparable.

The data was then randomised and separated into 3 groups, allocated as the training, validation and testing data sets, respectively. The training data set contained the majority of the data points (70\%) and was used to train the various models' behaviours and assign numerical values to various coefficients. The validation data (8\%) set was used to make sure the regression/learning technique was not 'overtrained' and unable to generalise. The validation set is designed to automatically stop optimisation once its mean squared error (MSE) value starts to rise during the iterative training operation. The testing data $(22 \%)$ was then used to determine the effectiveness of the models, by comparing its predictions with virgin data.

The evaluation of the various modelling techniques was analysed via calculating the MSE between the predicted results and the actual results across the testing data sets. The effects of changing process input values were determined via an individual input sensitivity analysis. All inputs were set to their mean values while a single input was varied from normalised values of 0 to 1 along its range. The simulated output was calculated via the corresponding model and therefore the results obtained were solely influenced by the variation of a single parameter. It provides a unique opportunity to localise the impact of a single input without changing the 
others. This technique is useful as similar investigations are not practical or are too expensive/time consuming to obtain via physical experimentation.

The modelling was performed using the MATLAB software. The type of function codes being used in this investigation to analyse the process behaviour are listed in Table II. The modes of analysis used and their relevant MATLAB functions are also listed in the Table II. The modelling architecture used for each modelling technique is described in Table III.

Table II: A list of various MATLAB functions used in various modelling techniques implemented.

\begin{tabular}{|c|c|c|c|}
\hline Modelling Technique & Type of Model & MATLAB Function & Test Location Batch \\
\hline $\begin{array}{c}\text { Multiple Linear } \\
\text { Regression (MLR) }\end{array}$ & Multivariate Linear Regression & Regress & $\begin{array}{c}\text { Separated Test Location } \\
\text { Analysis }\end{array}$ \\
\hline $\begin{array}{c}\text { Multiple Quadratic } \\
\text { Regression (MQR) }\end{array}$ & Multivariate Linear Regression & Regsats & $\begin{array}{c}\text { Separated Test Location } \\
\text { Analysis }\end{array}$ \\
\hline Neural Network & $\begin{array}{c}\text { Multivariate Non-Linear Regression, } \\
\text { Feed Forward Back Propagation }\end{array}$ & Newff, NET \& Sim & $\begin{array}{c}\text { Separated Test Location } \\
\text { Analysis }\end{array}$ \\
\hline $\begin{array}{c}\text { Ensemble Neural } \\
\text { Network }\end{array}$ & $\begin{array}{c}\text { Multivariate Non- Linear Regression, } \\
\text { Feed Forward Back Propagation }\end{array}$ & Newff, NET \& Sim & $\begin{array}{c}\text { Separate Test location } \\
\text { Analysis }\end{array}$ \\
\hline $\begin{array}{c}\text { Randomised Ensemble } \\
\text { Neural Network }\end{array}$ & $\begin{array}{c}\text { Multivariate Non- Linear Regression, } \\
\text { Feed Forward Back Propagation }\end{array}$ & Newff, NET \& Sim & $\begin{array}{c}\text { Combined Test Location } \\
\text { Analysis }\end{array}$ \\
\hline $\begin{array}{c}\text { Xvalidation Ensemble } \\
\text { Neural Network }\end{array}$ & $\begin{array}{c}\text { Multivariate Non- Linear Regression, } \\
\text { Feed Forward Back Propagation }\end{array}$ & Newff, NET \& Sim & $\begin{array}{c}\text { Combined Test Location } \\
\text { Analysis }\end{array}$ \\
\hline
\end{tabular}

Table III: A list of various model designs used in various modelling techniques implemented.

\begin{tabular}{|c|c|c|c|c|}
\hline $\begin{array}{c}\text { Modelling } \\
\text { Technique }\end{array}$ & No of Models & $\begin{array}{c}\text { No. of data } \\
\text { points per Model }\end{array}$ & $\begin{array}{c}\text { Training } \\
\text { Algorithm }\end{array}$ & $\begin{array}{c}\text { Network } \\
\text { Topography }\end{array}$ \\
\hline $\begin{array}{c}\text { Multiple Linear } \\
\text { Regression (MLR) }\end{array}$ & $\begin{array}{c}\text { 1 per test location } \\
\text { per tensile property (32) }\end{array}$ & 333 (mean) & - & - \\
\hline $\begin{array}{c}\text { Multiple Quadratic } \\
\text { Regression (MQR) }\end{array}$ & $\begin{array}{c}\text { 1 per test location } \\
\text { per tensile property (32) }\end{array}$ & 333 (mean) & - & - \\
\hline Neural Network & $\begin{array}{c}\text { 1 per tensile location } \\
\text { per tensile property (32) }\end{array}$ & 333 (mean) & trainrp & $36-24-12-1$ \\
\hline $\begin{array}{c}\text { Ensemble Neural } \\
\text { Network }\end{array}$ & $\begin{array}{c}10 \text { per each ensemble model } \\
\text { per tensile location } \\
\text { per tensile property (320) }\end{array}$ & 333 (mean) & trainrp & $36-24-12-1$ \\
\hline $\begin{array}{c}\text { Randomised Ensemble } \\
\text { Neural Network }\end{array}$ & $\begin{array}{c}10 \text { per each ensemble model } \\
\text { per tensile property (40) }\end{array}$ & 2660 & trainlm & $30-15-1$ \\
\hline $\begin{array}{c}\text { Xvalidation Ensemble } \\
\text { Neural Network }\end{array}$ & $\begin{array}{c}10 \text { per each ensemble model } \\
\text { per tensile property (40) }\end{array}$ & 2660 & trainlm & $30-15-1$ \\
\hline
\end{tabular}

Detailed information on these models, modelling techniques, training algorithms and network topography can be found in the MATLAB specified literature [1,2].

\section{Results}

A comparison of the accuracy of all the models used across all tensile properties is shown in Figure 1.

With regards to the strength trends, there is a decrease in MSE with evolution in regression technique. The combined test location methods are similar in magnitude to simpler models, even with a higher data set value and thus the likelihood for increased errors. However, the practical 
recording of the measurements are more qualitative than the strength based values and to a lesser degrees of accuracy. Therefore the values shown may still be practically applicable. The actual Root Mean Squared Error (RMSE) values show an accuracy of between approximately 1.2$3.5 \%$, which may be suitable as an early warning sign warning during process design.

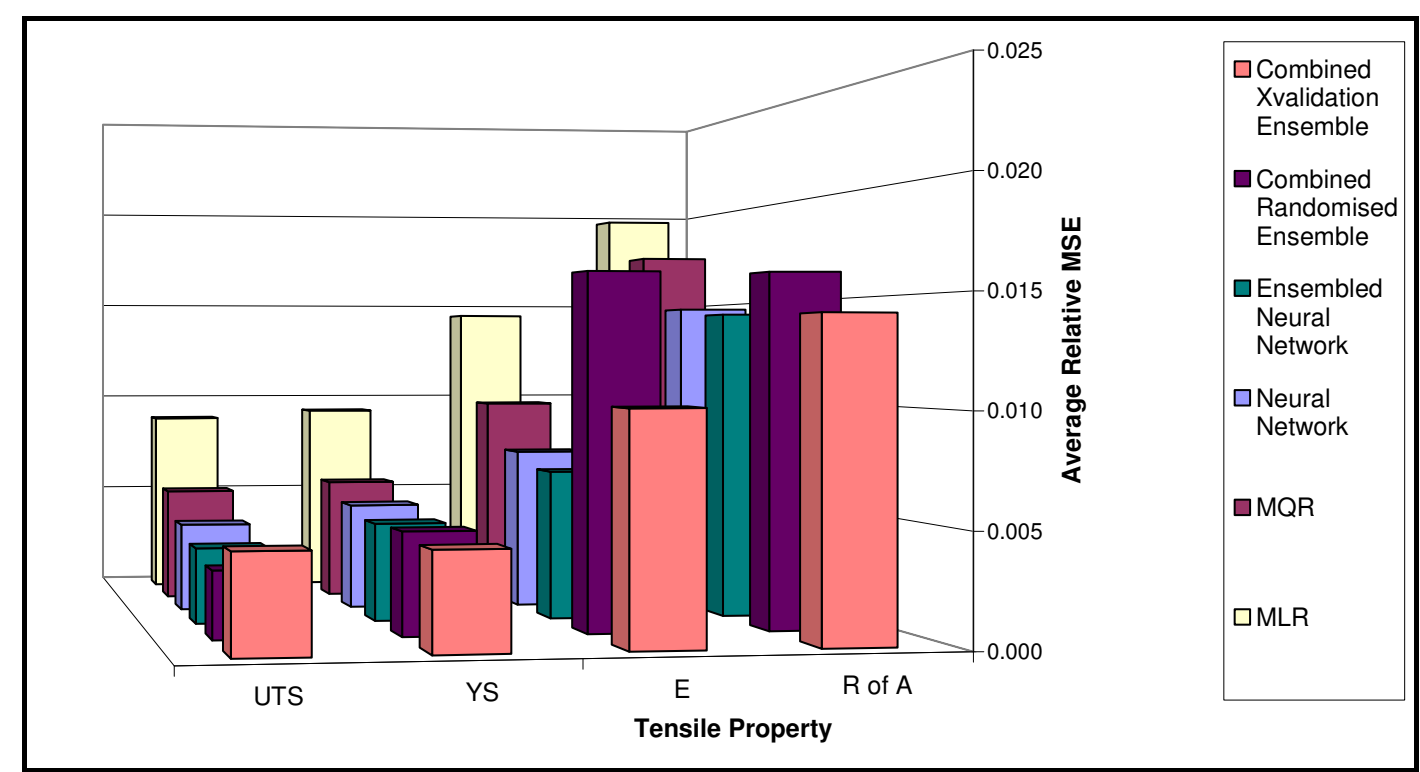

Figure 1: Variation in Average Testing MSE results at all test locations for each method of analysis.

The tests results in Figure 2. show that the models are better at the predictive behaviour of the strength based tensile results than the ductility based results. The black and red lines represent the $\pm 5 \%$ of the normalised and actual data ranges respectively. With the strength results, the models operate well inside this range and mostly keep their confidence limits concise. With the ductile traits, both the confidence ranges are of similar magnitudes and the confidence limits are respectively larger. The ensembled models have a greater difficulty predicting the nature of the ductile trends.

There are three possible reasons for this behaviour: 1. there is not sufficient data provided to describe the behaviour of the ductile traits and some additional quality measures are required as process inputs; 2 the network topography is too simplistic to generalise the behaviours properly; and 3. there are too many unquantifiable qualitative variations that occur during operation/recording $\mathrm{R}$ of $\mathrm{A}$, which have an influence but are unable to be quantified and therefore modelled, via these methods.

\section{$\underline{\text { Input Sensitivity Models }}$}

The input sensitivity results illustrated in this paper are those obtained from the 'combined' methods with the lowest MSE. These will highlight the process route influences over one specific test location (Figure 3). The results are plot as normalised groups of 7 for convenience and the 'test location' variable is a constant throughout and therefore is not plot. Each set of 7 
inputs are plot in the same column for all its tensile correlations so direct comparisons may be made between them.

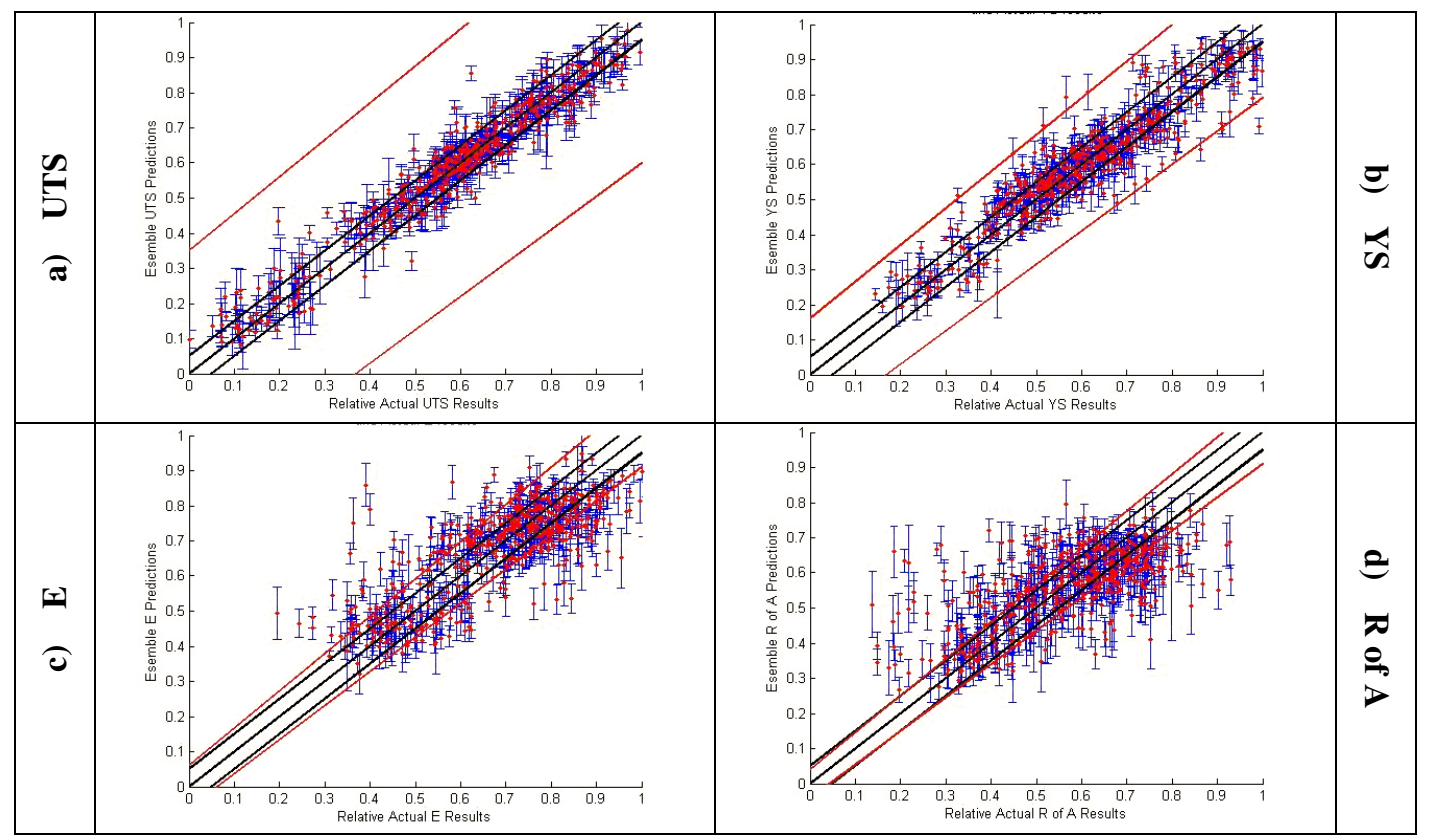

Figure 2 a-d) : Diagonal Plots Predictions of testing data for best neural networks across all tensile properties.

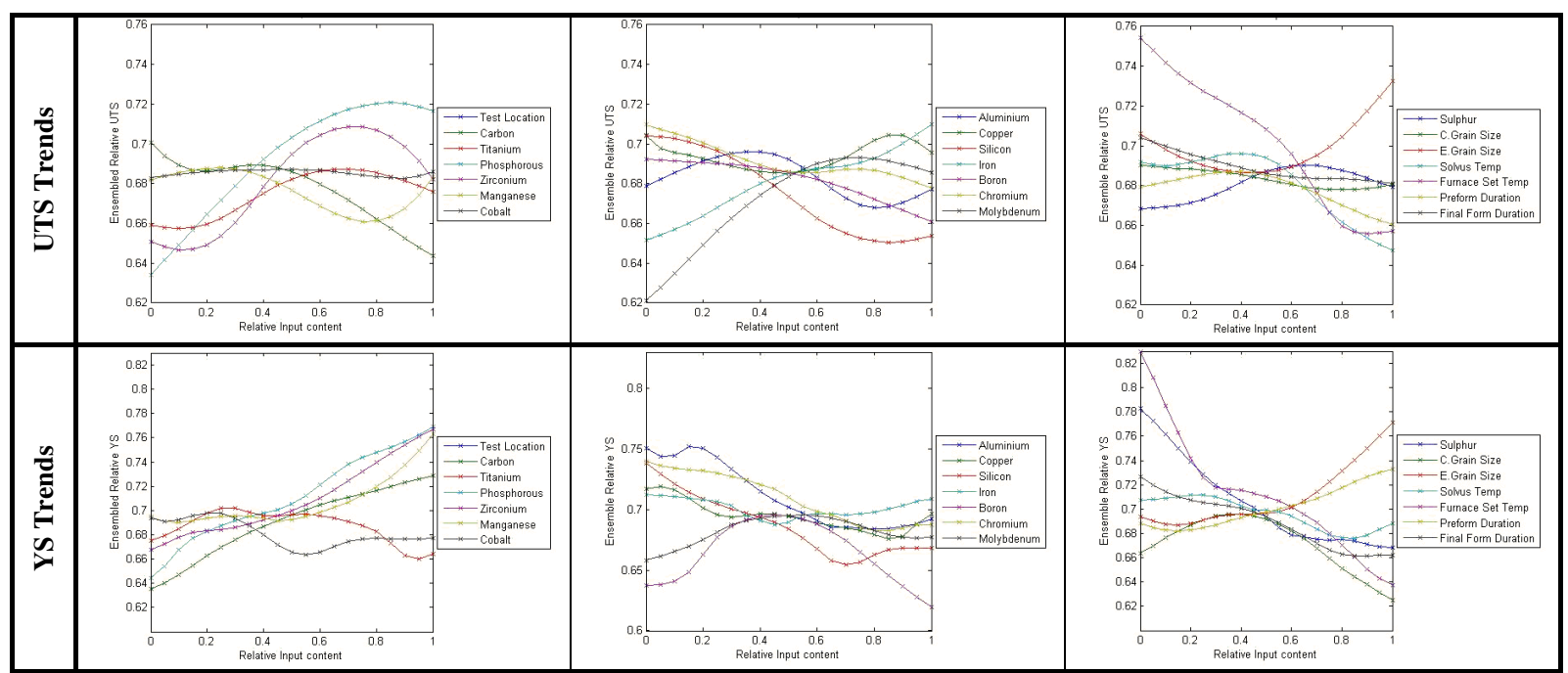

Figure 3a: The influence of varying inputs across the strength based properties, taken at test location 3. 


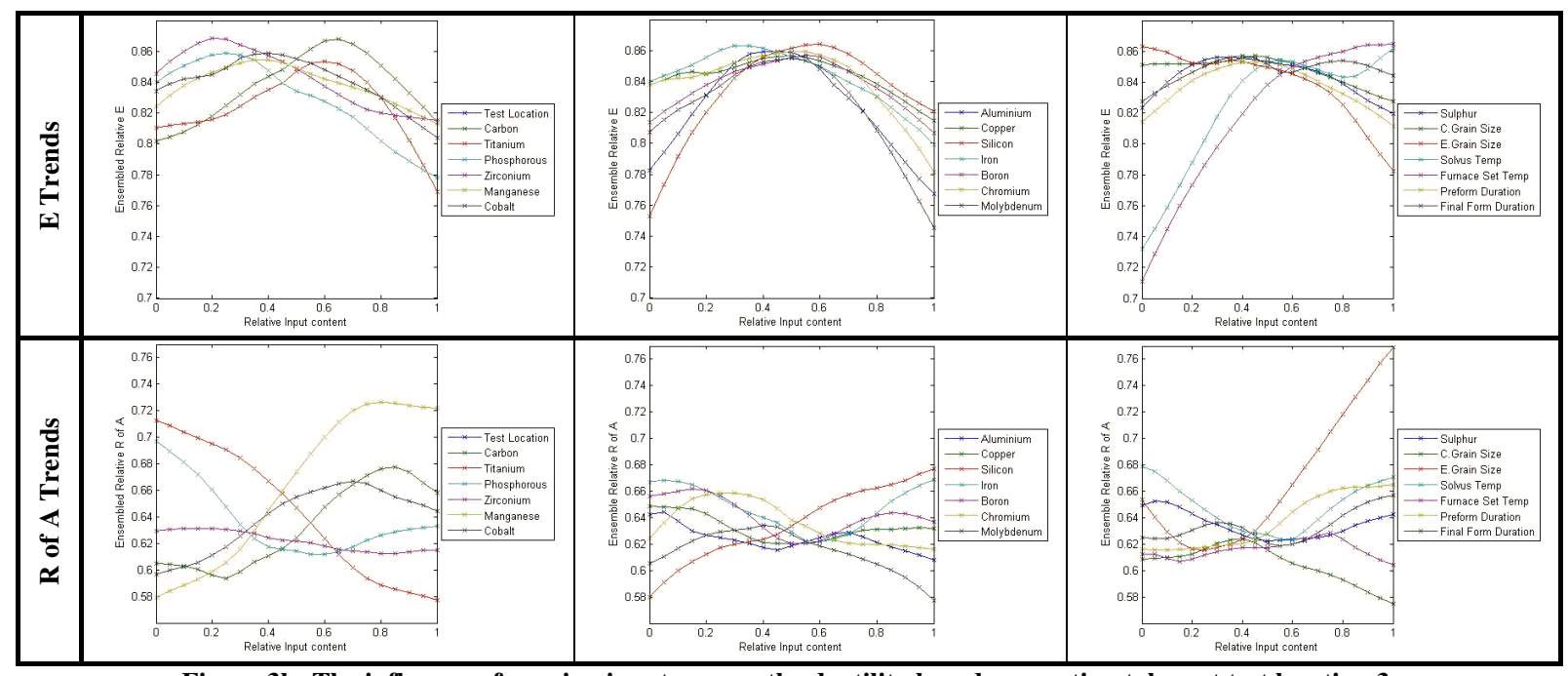

Figure 3b: The influence of varying inputs across the ductility based properties, taken at test location 3.

The models also allow a surface plot to be created showing how interacting inputs jointly affect a given tensile property (Figure 4). So for example, using Figure 4, one could analyse what the most effective ratio of $\gamma^{\prime}\left(\mathrm{Ni}_{3},(\mathrm{Al}, \mathrm{Ti})\right)$ additions promote the best UTS. Another use would be to calculate how much the final form heat treatment duration needs to be increased to compensate for a short preform duration operation, while keeping a satisfactory $\mathrm{R}$ of $\mathrm{A}$. Care must also be taken in the analysis of such trends. Any input shown not having any impact on the tensile properties in this study may have one (or another purpose) in reality. It may not show up due to there not being enough variation in its values across the 2660 data points.
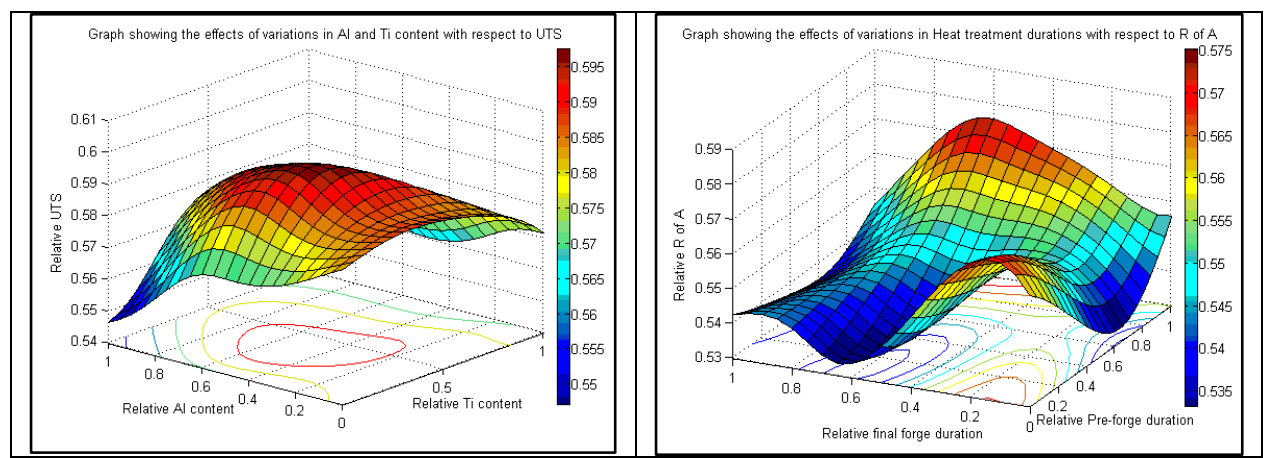

Figure 4a-b: Surface plots showing the impact of two alternating inputs and their joint impact on a given tensile property. (Note, relationships have been derived from separated ensembled results, and not from combined test location analyses, hence they may not match with correlations shown in Figure 3.

Since various models are produced using different randomised sets of data for different test location models or among the ensemble model batch, repeated trends may be used to assure process metallurgist that the models are picking out consistent behaviour. An example of a trend consistency analysis has been performed on the best obtained models from the combined test location analysis and is summarised in Table IV simply comparing one strength property against a ductile one. 


\section{$\underline{\text { Strength and Ductility Trends (YS and E) }}$}

Table IV shows if the input has a positive or negative correlation with a specified tensile property. More complex relationships are also described across the data ranges (if applicable). The table also highlights how many test locations share similar responses to one another, which can highlight a forging's anisotropic tendencies or be used as a further element of assurance in the modelling behaviour. The influence of each input has also been highlighted, so if only subtle variations are required, then milder influencing inputs may be altered and vice versa for drastic changes.

Table IV: Table showing impact of various inputs on YS and E traits,

\begin{tabular}{|c|c|c|c|c|}
\hline Input & Trend with YS & Influence & Trend with $\mathbf{E}$ & Influence \\
\hline $\mathbf{C}$ & $\begin{array}{l}\text { Positive based on } 8 \text {, keep between } 0.2-1 \text { for best } \\
\text { control }\end{array}$ & Strong & Negative/Minimise & Intermediate \\
\hline $\mathbf{T i}$ & $\begin{array}{l}\text { Mild Positive based on } 4 \text {, No impact based on } 5 \text {, } \\
\text { may maximise for the minority. Needs validation }\end{array}$ & Mild/n/a & $\begin{array}{l}\text { Negative, peak at } 0.6 / 0.7 \text { (limit to } \\
0-0.6 \text { for best control) }\end{array}$ & Strong \\
\hline $\mathbf{P}$ & Positive based on 7,3 across range, 4 over $0.5-1$ & Strong & No impact, minor positive & Mixed/weak \\
\hline $\mathbf{Z r}$ & $\begin{array}{l}\text { Positive based on } 5 / 7 \text {, may be detrimental over } 0 \text { - } \\
0.5 \text { for some }\end{array}$ & Strong & $\begin{array}{l}\text { Negative, limit range to } 0.2- \\
0.75 / 1 \text { for best control }\end{array}$ & Strong \\
\hline Mn & $\begin{array}{l}\text { Positive overall. Positive based on } 7 \text { with best } \\
\text { control above } 0.5 \text {, negative based on } 5 \text { up to } 0.5 \\
\text { ( } \mathrm{x}^{2} \text { relationships) }\end{array}$ & Strong & $\begin{array}{l}\text { Net mild negative impact } \\
\text { (unknown trend, validate) }\end{array}$ & Mixed \\
\hline Co & $\begin{array}{l}\text { Negative based on } 6,0 \text { value is best, needs } \\
\text { validation }\end{array}$ & Strong & $\begin{array}{l}\mathrm{x}^{2} \text { relationship with net positive, } \\
\text { best control from } 0.35-0.5\end{array}$ & Mild \\
\hline Al & Negative based on 8 , best control between $0.3-0.7$ & Varied & Negative based on 6 & Intermediate \\
\hline $\mathbf{C u}$ & $\begin{array}{l}\text { Negative based on } 4 \text {, no impact at } 2 \text {, mild } \\
\text { positive at } 3 \text {, minimise overall but needs } \\
\text { validation }\end{array}$ & Mixed & $\begin{array}{l}\text { No impact at } 4, \text { negative at } 4 \text {, } \\
\text { need to verify trend, potential to } \\
\text { minimise }\end{array}$ & $\begin{array}{c}\mathrm{n} / \mathrm{a} \\
\text { / very weak }\end{array}$ \\
\hline $\mathbf{S i}$ & $\begin{array}{l}\text { Negative based on } 5 \text {, keep at } 0 \text {, best control over } \\
0.7-1\end{array}$ & $\begin{array}{c}\text { Strong/ } \\
\text { Intermediate }\end{array}$ & Positive based on 6 & Strong \\
\hline $\mathbf{F e}$ & $\begin{array}{l}\text { Positive based on } 7 \text {, keep from } 0.35-1(0.35-1 \\
\text { based on } 4,0.5-1 \text { based on } 3)\end{array}$ & Intermediate & $\begin{array}{l}\text { Negative based on } 8 \text { (may be } \\
\text { limited impact above } 0.5 \text { ) }\end{array}$ & Strong \\
\hline $\mathbf{B}$ & Negative based on $61 / 2$ & Intermediate & Unknown (leave and validate) & $\mathrm{n} / \mathrm{a}$ \\
\hline $\mathbf{C r}$ & $\begin{array}{l}\text { Bimodal, } \mathrm{x} 2 \text { at } 6 \text {, limit content to maximum of } \\
0.5 / 0.7 \text {, needs industrial validation }\end{array}$ & Unknown & $\begin{array}{l}\text { Negative based on } 4 / 6 \text {, best } \\
\text { control over } 0.5-1\end{array}$ & Strong \\
\hline Mo & $\begin{array}{l}\text { Strong negative based on } 3 \text {, mild positive based } \\
\text { on } 3 \text {, do not trust strength of negative trends, } \\
\text { needs validation }\end{array}$ & Mixed & $\begin{array}{l}\text { Negative based on } 8 \text { ( } 4 \text { are net } \\
\text { negative) }\end{array}$ & Very strong \\
\hline $\mathbf{S}$ & $\begin{array}{l}\text { Negative at } 5, \text { shift in behaviour mostly observed } \\
\text { at } 0.45\end{array}$ & $\begin{array}{c}\text { Strong/ } \\
\text { Intermediate }\end{array}$ & $\begin{array}{l}\text { No impact based on } 4 \text { (unknown), } \\
\text { short range positive across } 0.3- \\
0.7 \text {, needs validation }\end{array}$ & Mild \\
\hline $\begin{array}{c}\text { Inner } \\
\text { G }\end{array}$ & $\begin{array}{l}\text { No impact based on } 4 \text {, best results between } 0.4- \\
0.55 \text { at } 4 \text {, leave alone or isolate ideal region, } \\
\text { needs validation }\end{array}$ & $\mathrm{n} / \mathrm{a}$ & No impact at 6 , leave alone & $\mathrm{n} / \mathrm{a}$ \\
\hline $\begin{array}{c}\text { Outer } \\
\text { G }\end{array}$ & Negative at 8 , best control over $0.35-1$ & Strong & $\begin{array}{l}\text { Negative, based on } 7 \text {, best control } \\
\text { over } 0.4-1\end{array}$ & Very Strong \\
\hline $\begin{array}{c}\gamma^{\prime} \\
\text { Solvus } \\
\text { Temp }\end{array}$ & $\begin{array}{l}\text { Positive based on } 3 \text {, Negative based on } 3, \\
\text { indecisive, compare to other network trends } \\
\text { (should be positive) }\end{array}$ & Mixed & $\begin{array}{l}\text { Positive based on } 8 \text {, best control } \\
\text { over } 0-0.5\end{array}$ & Strong \\
\hline $\begin{array}{l}\text { Fur. } \\
\text { Set } \\
\text { Temp }\end{array}$ & Negative based on 8 & $\begin{array}{l}\text { Very } \\
\text { strong }\end{array}$ & $\begin{array}{l}\text { Positive based on } 6 \text {, control } \\
\text { above } 0.6 \text { is weak }\end{array}$ & Strong \\
\hline $\begin{array}{l}\text { Preheat } \\
\text { Dur. }\end{array}$ & $\begin{array}{l}\text { Positive based on } 5 \text {, negative based on } 3 \text {, } \\
\text { maximise }\end{array}$ & Mild & No impact at 5, leave alone & $\mathrm{n} / \mathrm{a}$ \\
\hline $\begin{array}{l}\text { Final } \\
\text { Dur. }\end{array}$ & Negative based on 6 & neglible & $\begin{array}{l}\text { No impact at } 5, \text { mild positive } \\
\text { at best, leave alone/optimise }\end{array}$ & $\begin{array}{l}\mathrm{n} / \mathrm{a} \\
\text { / mild }\end{array}$ \\
\hline
\end{tabular}


To further expand the work, an extended hybrid modelling technique may be introduced, which allows for the combination of empirical flow and data modelling methods. This will provide a knowledge-based grey box solution (with minimal extra additional inputs) that enhances the models ability to model the process route more accurately.

\section{Conclusions}

Industrial data has been used to create a number of statistical models to predict mechanical properties of forged Waspaloy components as a function of a multivariate data set. This has enabled the following:

- Optimise model design for stronger correlations between process route and forging quality

- Determine process route influences on the quality of finished forging components.

- Observe variations in model/predictive quality across varying process outputs

- Identify the severity of input influences on various outputs

- Compare the influence of multiple interacting inputs simultaneously

- Compare the influence on multiple outputs simultaneously

- Compare the variation in process route behaviour across multiple testing locations.

- Influence process design to optimise products, based on cost, performance, reduction of nonconformance, machine limitations, environmental legislation etc...

\section{References}

1. Demuth H, Hagan M, Beale M, Neural Network Toolbox ${ }^{\mathrm{TM}}$ 6-User's Guide, Chapters 1-5 Mathwork ${ }^{\mathrm{TM}}$ Publication, Revised for Version 6.0.4, March 2010.

2. Statistics Toolbox ${ }^{\mathrm{TM}}-7$ User's guide, Chapter 9 Regression Analysis, Mathwork ${ }^{\mathrm{TM}}$ publication, Revised for Version 7.3, March 2010 (author unknown). 